\title{
Antibiotic resistant microencapsulated probiotics synergistically preserved orange juice
}

Md Shahid Hossain ${ }^{1}$, Md Abdul Alim Al-Bari ${ }^{*}$, Zahid Hayat Mahmud² and Mir Imam Ibne Wahed

\begin{abstract}
Background: In contemporary medicine, the utilization of various dosage forms of probiotics is increasing both for the treatment of human and animal diseases in Bangladesh. A number of imported pharmaceutical probiotic preparations are available in the local markets at present without justification the scientific information of viability. This study was, therefore, designed to explore the viability of commercial probiotics as well as recommend the consumers for the better products in term of viability. Since probiotics preserved foods have expanded in acceptance, popularity and compliance, the goal of this research was also to investigate the combination effects of lactic acid bacteria (LAB) on development of functional foods like orange juice (OJ).
\end{abstract}

Methods: Here, we screened five commercially available pharmaceutical probiotic products for rejuvenation and identification of $\angle A B$ and associated resistance against different classes of antibiotics. Finally, the isolated $L A B$ were microencapsulated and compared with free form of bacteria for biopreservation of OJ.

Results: We observed an inconsistency between the feasible live $L A B$ counts and the declaration of the manufacturing companies. The recovered viable bacteria of pharmaceutical probiotic preparations ranged between $(6.2-7.3) \times 10^{10}$ at $37^{\circ} \mathrm{C}$ and $(5.33-7.1) \times 10^{10}$ at $25^{\circ} \mathrm{C}$, the claimed (9-10) $\times 10^{10}$ colony forming unit (CFU)/g. The encapsulated Lactobacillus acidophilus (LAB 1), L. bulgaricus (LAB 2), Lactococcus lactis (LAB 3) and Bifidobacterium bifidum (LAB 4) in OJ was resistant to drop out their viability as quickly as the free-form probiotic bacteria and $>10^{6} \mathrm{CFU} / \mathrm{mL}$ were still appeared after 6 wks of storage. Unencapsulated probiotics was found to have a significant reduction in viability in OJ at both $37^{\circ} \mathrm{C}$ and $4{ }^{\circ} \mathrm{C}$ temperatures. However, the microencapsulation process significantly reduced the loss of viability of four probiotic bacteria as well as the control of acidification of OJ at $4{ }^{\circ} \mathrm{C}$.

Conclusions: The loss of potency and spoiled food associated with pathogenic microbial growth are serious problems in tropical countries including Bangladesh. The biopreserved OJ will become an important functional food due to its expansion of shelf-time, market reputation, profits and innate tastes. This report has an indication that the combination of these four LAB may become good candidate for the development of an OJ with functional characteristics.

Keywords: Microencapsulated lactic acid bacteria, Antibiotic sensitivity, Orange juice, Functional food

Abbreviations: Amx, Amoxicillin; Cef, Ceftazidime; CFS, Cell-free supernatant; Chlor, Chlorampenicol; Cipro, Ciprofloxacin; Dox, Doxycycline; Eryth, Erythromycin; Kan, Kanamycin; LAB 1, Lactobacillus acidophilus; LAB 2, L. bulgaricus; LAB 3, Lactococcus lactis; LAB 4, Bifidobacterium bifidum; LAB, Lactic acid bacteria; M:P, ratio 1:5, Methyl paraben and propyl paraben; MB, Methyl-p-hydroxy benzoate; Pen G, Penicillin-G; SB, Sodium benzoate; Strep, Streptomycin; Tet, Tetracycline

\footnotetext{
* Correspondence: alimalbari347@ru.ac.bd

'Department of Pharmacy, University of Rajshahi, Rajshahi 6205, Bangladesh

Full list of author information is available at the end of the article
} International License (http://creativecommons.org/licenses/by/4.0/), which permits unrestricted use, distribution, and reproduction in any medium, provided you give appropriate credit to the original author(s) and the source, provide a link to the Creative Commons license, and indicate if changes were made. The Creative Commons Public Domain Dedication waiver (http://creativecommons.org/publicdomain/zero/1.0/) applies to the data made available in this article, unless otherwise stated. 


\section{Background}

In biopreservation technology, LAB are used to lengthen the shelf life and balance the growth and multiplication of internal pathogens in foods $[1,2]$. LAB yield a wide variety of compounds such as lactate, hydrogen peroxide $\left(\mathrm{H}_{2} \mathrm{O}_{2}\right)$ as well as antibiotics, bacteriocins that directly inhibit other microorganisms for their depletion of nutrition [3]. LAB are also joined with the formation of several foods and thus have typically recognized as safe (GRAS) status granted by the Food and Drug Administration (FDA) [4-6]. Furthermore, probiotic properties of some LAB provide a number of beneficial effects including regulation of intestinal microbial homeostasis and modulation of local and systemic immune responses [7].

Functional food is generally designated if it gives beneficial effects on body in addition to the classical nourishing value. Functional foods, for example OJ are prepared with bioactive "friendly" LAB [8]. Beyond the functional components, like vitamins and minerals, the inclusion of $\mathrm{LAB}$ in $\mathrm{OJ}$ can provide an effective means for the generation of healthy food with the increase in life expectancy $[8,9]$. Thus, development of foods with probiotic bacteria is one of the supreme research preferences in the food industry as well as nutripharmaceutical companies.

Advances in food science and technology has eliminated but not completely eradicated the food-borne diseases in developed countries. With consumers becoming more concerned about the levels of chemical preservatives present in food, bacteriocins secreted by LAB offer an alternative, more natural approach, while ensuring both food safety and product shelf life [10]. In order to fit the consumer interests with required quality compliance, the classical means of food processing and preservation are being replaced by various advance technologies as like microencapsulation. This trend of techniques has approved the utilization of LAB in biopreserved foods [11-14]. A lot of pharmaceutical probiotic products in various forms spread in the local markets without verification the scientific information such as identity of strains, probiotic properties and also viabilities. This study was, therefore, designed to investigate the viabilities of different commercial sources of probiotic products in Bangladesh as well as compared for the better products to the consumers. Resistance of antibiotic has appeared a serious threat for public health globally and is acquired the interest of health professionals and food scientists in all around the world. Since the consumption of commercial probiotics is increased, it is necessary to give sufficient protection to the consumers from any adverse reactions of the products. The quality and safety considerations of these probiotic strains are the prime prerequisite with resistance to antibiotics as an assessment issue. Since probiotic foods have gained widespread acceptance, the purpose of this study was also to formulate a functional food as prototype of $\mathrm{OJ}$ by using different combination of microencapsulated LAB.

\section{Methods}

\section{Sample collection and processing}

Samples of different pharmaceutical probiotics were obtained from local market. The brand names and respective pharmaceutical companies of probiotic products were Probio (Square Pharmaceuticals Ltd.); Prolacto (Drug International Limited); Protik Vitality (Kemiko Pharmaceuticals Ltd.) Bangladesh; Preotik (Meridian Medicare Ltd. India) and TS6 (Tensall Bio-Tech Co. Ltd. Taiwan) and the samples were designated as S1 to S5 (Table 1). For rejuvenation, recovery and enumeration of viable probiotic bacteria, the plate counts and spectroscopic assay $\left(\mathrm{OD}_{690 \mathrm{~nm}}\right)$ were performed as described previously [15]. Briefly, approximately $1 \mathrm{~g}$ of powder of individual pharmaceutical product (capsule or sachet) was mixed homogeneously with sterile phosphate buffered saline (9 mL PBS, $\mathrm{pH} 7.0$ ) and kept in an incubator for $1 \mathrm{~h}$ at $25{ }^{\circ} \mathrm{C}$. Then, the specimens were diluted in 10-times serially with PBS and $100 \mu \mathrm{L}$ of each diluted sample was then mixed well with deMan Rogosa and Sharpe (MRS) agar (Difco, USA) and incubated under anaerobic conditions at $25^{\circ} \mathrm{C}$ and $37{ }^{\circ} \mathrm{C}$ temperatures as well as pHs (4.5 and 6.5) under anaerobic and aerobic conditions for 24-48 h. After $48 \mathrm{~h}$ of incubation, 3-4 colonies were taken up and shifted to MRS broth and incubated for $24 \mathrm{~h}$. The pure cultures of colonies were streaked on MRS agar plates and incubated for further $24 \mathrm{~h}$ at $37{ }^{\circ} \mathrm{C}$. Individual strains were relocated to $2 \mathrm{~mL}$ MRS broth and purified by repeatedly plating on MRS agar. Then, the entire strains were examined the morphology with microscope and pure cultures were preferred

Table 1 Common lactic acid bacteria in probiotic products available in Bangladesh

\begin{tabular}{lllllll}
\hline No. & Lactic acid bacteria & \multicolumn{3}{l}{ Market sample } \\
\cline { 3 - 7 } & S1 & S2 & S3 & S4 & S5 \\
\hline i. & Lactobacillus acidophilus (LAB 1) & $\sqrt{ }$ & $\sqrt{ }$ & $\sqrt{ }$ & $\sqrt{ }$ & $\sqrt{ }$ \\
ii. & Lactobacillus bulgaricus (LAB 2) & $\sqrt{ }$ & $\sqrt{ }$ & $\times$ & $\times$ & $\times$ \\
iii. & Lactococcus lactis (LAB 3) & $\times$ & $\times$ & $\sqrt{ }$ & $\times$ & $\sqrt{ }$ \\
iv. & Lactobacillus casei & $\times$ & $\times$ & $\times$ & $\times$ & $\sqrt{ }$ \\
v. & Lactobacillus ramnosus & $\times$ & $\times$ & $\times$ & $\sqrt{ }$ & $\times$ \\
vi. & Bifidobacterium bifidum (LAB 4) & $\sqrt{ }$ & $\sqrt{ }$ & $\times$ & $\sqrt{ }$ & $\sqrt{ }$ \\
vii. & Bifidobacterium infantis & $\times$ & $\times$ & $\times$ & $\times$ & $\sqrt{ }$ \\
viii. & Bifidobacterium longum & $\times$ & $\times$ & $\times$ & $\sqrt{ }$ & $\sqrt{ }$ \\
ix. & Strepcoccus thermophyllus & $\times$ & $\times$ & $\times$ & $\sqrt{ }$ & $\times$ \\
x. & Saccharomyces boulardi & $\times$ & $\times$ & $\times$ & $\sqrt{ }$ & $\times$ \\
\hline
\end{tabular}

$\sqrt{ }$ indicated 'present' and $\times$ indicated 'absent' 
for additional studies. The final concentrations of overnight cultured colonies were made in uniformity values as $1.0 \times 10^{9} \mathrm{CFU} / \mathrm{mL}$ by spectroscopy $\left(\mathrm{OD}_{690 \mathrm{~nm}}\right)$ prior to antibiotic sensitivity tests using several antibiotic discs. Four LAB including Lactobacillus acidophilus (LAB1), L. bulgaricus (LAB2), Lactococcus lactis (LAB3) and Bifidobacterium bifidum (LAB4) were identified according to the methods described earlier [16]. The purified bacterial strains were kept at $-20{ }^{\circ} \mathrm{C}$ in $\mathrm{MRS}$ broth with an additive, $20 \%(\mathrm{v} / \mathrm{v})$ glycerol for future studies.

\section{In vitro antimicrobial activities}

For primary screening of antagonistic activities, the individual $L A B$ 1- 4 strains were transferred in MRS broth $(50 \mathrm{~mL})$ and mixed well in a shaker for $30 \mathrm{~min}$ and then cultured for $48 \mathrm{~h}$ at $37^{\circ} \mathrm{C}$. The cultures of LAB 1-4 were centrifuged for $15 \mathrm{~min}$ at $6000 \mathrm{rpm}$ and the supernatants were decanted into sterile test tubes marked as cell free supernatants (CFS 1-4). To examine the mechanisms of antimicrobial activities, the supernatants, CFS 1- 4 were adjusted to $\mathrm{pH} 7.0$ with $5 \mathrm{~N}$ sodium hydroxide $(\mathrm{NaOH})$ solution to exclude the effect of $\mathrm{pH}$. The neutralized CFS1- 4 were further reacted with $2 \mathrm{mg} / \mathrm{mL}$ catalase solution ( $\mathrm{pH} 7.0$ ) for $0.5 \mathrm{~h}$ at $25{ }^{\circ} \mathrm{C}$ to minimize the suppressive activities of hydrogen peroxide $\left(\mathrm{H}_{2} \mathrm{O}_{2}\right)$. Finally, the mixtures of CFS1- 4 were treated with $0.5 \mu \mathrm{g} / \mathrm{mL}$ proteinase $\mathrm{K}$ and incubated at $37{ }^{\circ} \mathrm{C}$ for $4 \mathrm{~h}$. The mixtures of the CFS1-4 were decontaminated with membrane filter (pore diameter, $0.22 \mu \mathrm{m}$ ) before loading to the well plates. For preliminary screening of bacteriocin like inhibitory substance (BLIS) activity, the respective cultures of LAB were inoculated in $100 \mathrm{~mL}$ of MRS broth medium and incubated for $48 \mathrm{~h}$ at $37{ }^{\circ} \mathrm{C}$ in culture flasks with optimum physicochemical conditions. Aliquots (10 mL in each) of CFS1-4 extracted with ethyl acetate 1:2 separately by vigorous vortexing for $5 \mathrm{~min}$ and repetitively for 2 times. Then, ethyl acetate layers from each isolated cultures were collected, evaporated at room temperature, individually marked as extracts (Ext 1- 4) and tested for BLIS activities against pathogenic bacteria. For synergistic antimicrobial activity, the different combinations $(1: 1,1: 1: 1$ and $1: 1: 1: 1)$ of BLIS extracted from LAB1-4 were mixed together and carried out the experiment. The antimicrobial activities of the LAB were performed by the agar well diffusion method accordingly by Georgieva et al. [17] with minor adjustment against pathogenic bacteria and fungi that were obtained from ICDDR'B, Dhaka. Shortly, the fresh culture (24 h) of pathogenic bacteria was immersed uniformly in nutrient agar. Then different concentrations $(25,33,50$ and $100 \mu \mathrm{L}$ or $\mu \mathrm{g}$ ) of CFS1-4 or Ext1-4 were applied and the agar plates were incubated at $37{ }^{\circ} \mathrm{C}$ for $24 \mathrm{~h}$. The diameters of inhibitory zone were measured. The experiments were performed three times and the averages of the clear zones (greater than $6 \mathrm{~mm}$ in diameter) were recorded.

\section{Antibiotic resistance test}

In this study, the 10 antibiotic discs were used to determine antibiotic sensitivity of pathogenic bacteria and LAB1-4 strains. The antibiotic discs such as amoxicillin (30 $\mu \mathrm{g})$; ceftazidime (30 $\mu \mathrm{g})$; ciprofloxacin (5 $\mu \mathrm{g})$; tetracycline $(30 \mu \mathrm{g})$; chloramphenicol $(30 \mu \mathrm{g})$; erythromycin $(15 \mu \mathrm{g})$; doxycycline $(30 \mu \mathrm{g})$; kanamycin $(5 \mu \mathrm{g})$; penicillin-G $(10 \mu \mathrm{g})$ and streptomycin $(10 \mu \mathrm{g})$ were purchased from HiMedia, India. For comparison, three food chemical preservatives such as sodium benzoate $(0.1 \% \mathrm{w} / \mathrm{v})$; methyl-p-hydroxy benzoate $(0.1 \% \mathrm{w} / \mathrm{v})$ and the (1:5) solution of methyl- and propyl paraben $(0.1 \% \mathrm{w} / \mathrm{v})$ were used in this study. The susceptibility tests for each pathogenic bacterium and LAB were performed using disc diffusion method [15]. The antibiotic susceptibilities were determined by the inhibitory zone formation and compared according to Vandepitte et al. [18].

\section{Preparation of orange juice (OJ)}

The high quality oranges (scientific name Citrus sinensis) were selected, segmented and the seeds were removed manually from the slices. The extraction of $\mathrm{OJ}$ was done by using blender and sterile filter. The OJ was stored in sterilized clean containers at $4{ }^{\circ} \mathrm{C}$ for sequential works. It is to be mentioned that no chemical preservatives were added to the $\mathrm{OJ}$ and a long shelf life were determined accordingly $[19,20]$. In order to select for suitable growth condition of LAB, freshly prepared OJ (unadjusted $\mathrm{pH}$ 3.95-4.2) was modified for $\mathrm{pH}$ range (2.0-7.0) with citric acid-sodium citrate buffer solutions (Sigma Chemical Co.) and the viability of LAB in OJ was examined. For turbidity test, the absorbance of OJ before and after inoculation of LAB was determined at $540 \mathrm{~nm}$ with the help of UV spectrophotometer. The buffered OJ was inoculated with individual LAB1-4 and several blending of LAB as indicated previously and their viabilities for 4-6 wks duration were measured in MRS broth medium using 0.1-1.0 \% inoculum, incubating at $37{ }^{\circ} \mathrm{C}$. The MRS broth was removed completely by repeated washing in sterile PBS before inoculating the bacterial cells into OJ. Different combinations of LAB suspensions were added in aliquots of $\mathrm{OJ}(50 \mathrm{~mL}$ in each) and incubated them for $48 \mathrm{~h}$ at $37{ }^{\circ} \mathrm{C}$. Then, free-form LAB in OJ was preserved for $5-6 \mathrm{wks}$ at $4{ }^{\circ} \mathrm{C}$ in order to measure the viability of $L A B$.

Individual LAB1- 4 were cultured statically in $100 \mathrm{~mL}$ MRS broth for $18 \mathrm{~h}$ at $37{ }^{\circ} \mathrm{C}$, centrifuged for $15 \mathrm{~min}$ at $4{ }^{\circ} \mathrm{C}$ with speed $4000 \times \mathrm{g}$ and collected the pellets after rinsed with sterile PBS ( $\mathrm{pH} 7.4)$. Finally, individual $25 \mathrm{~mL}$ of LAB 1-4 solutions were prepared to obtain as 
approximately $10^{8} \mathrm{CFU} / \mathrm{mL}$ for both free-form and microencapsulated LAB. For microencapsulation, LAB 1-4 integrated into sodium alginate following a slight modification of method of Shah and Ravula [21]. Summarily, $100 \mathrm{~mL}$ of sterilized sodium alginate solution $(3 \% \mathrm{w} / \mathrm{v})$ was mixed well with PBS washed LAB 1-4 solution $(25 \mathrm{~mL})$ at $21^{\circ} \mathrm{C}$. The suspension of alginate and LAB 14 was dispensed gently into a beaker containing a solution of $1.0 \mathrm{gm}$ Tween 80 in $600 \mathrm{~mL}$ vegetable oil in order to form an emulsion. This emulsion was mixed well at constant speed (200 rpm) and mixed gradually with $0.1 \mathrm{M}$ calcium chloride solution into beaker until phase separation occurred in the emulsion. The beads of calcium alginate were preserved by decanting the oil phase after $0.5 \mathrm{~h}$, and stored for $10 \mathrm{~h}$ at $4{ }^{\circ} \mathrm{C}$ in order to allow the beads for complete hardness before being handled the experiments. The enumeration of free form of $\mathrm{LAB}$ and microencapsulated organisms were performed using methods illustrated by Zhang et al. [22] and Sohail et al. [13]. Enumeration of the LAB 1-4 in OJ was accomplished by consecutive 6 wks by culturing these organisms in MRS medium for $48 \mathrm{~h}$ in an anaerobic jar at $37^{\circ} \mathrm{C}$.

\section{Statistical analysis}

All the experiments performed here were carried out in triplicate and the results were expressed as mean \pm S.D (standard deviation). Analysis of statistical data was evaluated by using Student's $t$-test $\left({ }^{*} p<0.05\right.$, *** $p<0.01$, *** $p<0.005$, n.s.: not significant, throughout the manuscript).

\section{Results}

Probiotic bacteria, most of the Lactobacilli strains, collected from different pharmaceutical industries were rejuvenated and rescued successfully on MRS media and their statistics was given in Table 1 and Fig. 1. The obtained bacteria have a wide variety of colony morphologies and finally four distinguishing bacteria were selected for identification and characterization [16]. The outcomes indicate that several probiotic strains were present in the corresponding brands and this was expected with the specifications of the respective companies. However, the bacteria counts indicated that all of the samples had lower numbers of probiotics than that declared by their producers (Fig. 1) and the results were consistent with other reports [23, 24]. Most importantly, the viable bacteria counts in S4 and S5 were between 100 and 1000 times lower than claimed in their respective datasheets.

\section{Antimicrobial activities}

The antagonistic activities of cell-free supernatants (CFSs) of LAB against pathogenic Gram- positive and negative bacteria, and fungi were detailed in Tables 2, 3 and 4 . The results suggested that CFS1 and 3 had significant antimicrobial activities against all tested pathogenic bacteria and fungi and the CFS2 and 4 had moderate suppressive properties (Table 3 ). The antimicrobial activities of $\mathrm{LAB}$ were originated by the secretion of lactic acid, $\mathrm{H}_{2} \mathrm{O}_{2}$ or bacteriocin-like metabolites. To evaluate the inhibitory mechanism, at first the CFS1- 4 were treated with $5 \mathrm{~N} \mathrm{NaOH}$ to eliminate the effects of secreting acids indicating that the CFS1- 4 contained $\mathrm{H}_{2} \mathrm{O}_{2}$ or bacteriocin-like metabolites. The results of neutralization of acid in CFS1- 4 indicated a mild decrease of antibacterial and antifungal properties. In order to determine if a combination of LAB would have a synergistic inhibitory effect on the growth of certain pathogens, we used different fractions of CFSs and extracts

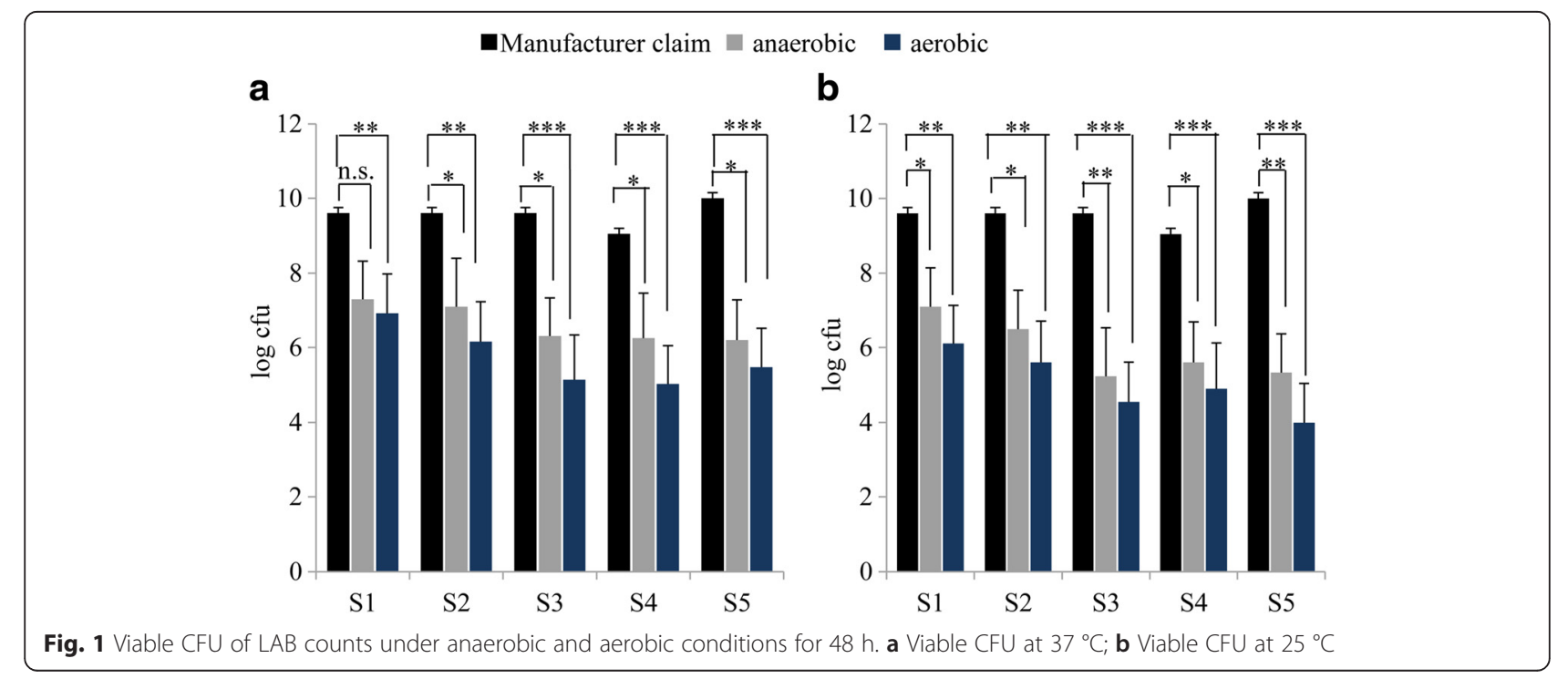


Table 2 Antagonistic activities of $L A B$ with different physicochemical treatments. Screening of antimicrobial activities of $L A B$ after different treatment of cell free supernatants (CFS)

\begin{tabular}{|c|c|c|c|c|c|c|c|c|c|}
\hline Treatment & B. cereus & B. subtilis & $\begin{array}{l}\text { Staphyl. } \\
\text { aureus }\end{array}$ & E. coli & Shi. dysenteriae & Shi. sonnei & $\begin{array}{l}\text { Saccharomyces } \\
\text { cerevisiae }\end{array}$ & $\begin{array}{l}\text { Aspergillus } \\
\text { niger }\end{array}$ & C. albicans \\
\hline LAB1 CSF $(100 \mu \mathrm{l})$ & ++++ & ++++ & ++++ & ++++ & ++++ & ++++ & +++ & +++ & +++ \\
\hline Neutralized by $\mathrm{NaOH}$ & +++ & +++ & ++ & +++ & +++ & ++ & +++ & ++ & ++ \\
\hline Catalase & ++ & ++ & ++ & +++ & ++ & ++ & ++ & ++ & + \\
\hline Protease K & + & - & + & + & + & ++ & - & + & + \\
\hline Heat $121{ }^{\circ} \mathrm{C}$ for $15 \mathrm{~min}$ & +++ & +++ & +++ & +++ & +++ & +++ & ++ & ++ & ++ \\
\hline LAB2 CSF $(100 \mu \mathrm{l})$ & ++ & +++ & ++ & ++ & + & ++ & + & + & + \\
\hline Neutralized by $\mathrm{NaOH}$ & ++ & +++ & ++ & ++ & + & ++ & + & + & + \\
\hline Catalase & ++ & ++ & ++ & ++ & + & ++ & + & + & + \\
\hline Protease K & + & + & + & + & - & - & - & - & + \\
\hline Heat $121^{\circ} \mathrm{C}$ for $15 \mathrm{~min}$ & + & + & + & + & - & - & - & - & + \\
\hline LAB3 CSF $(100 \mu \mathrm{l})$ & ++++ & +++ & +++ & +++ & +++ & ++++ & ++ & ++ & ++ \\
\hline Neutralized by $\mathrm{NaOH}$ & +++ & +++ & +++ & +++ & ++ & +++ & $+/-$ & + & + \\
\hline Catalase & ++ & ++ & ++ & ++ & ++ & ++ & + & + & ++ \\
\hline Protease K & + & - & + & + & + & ++ & ++ & $+/-$ & + \\
\hline Heat $121{ }^{\circ} \mathrm{C}$ for $15 \mathrm{~min}$ & +++ & ++ & ++ & +++ & ++ & ++ & ++ & + & ++ \\
\hline LAB4 CSF $(100 \mu \mathrm{l})$ & ++ & + & +++ & +++ & ++ & ++ & ++ & ++ & + \\
\hline Neutralized by $\mathrm{NaOH}$ & + & + & ++ & ++ & ++ & ++ & ++ & ++ & + \\
\hline Catalase & ++ & + & +++ & ++ & ++ & ++ & ++ & ++ & + \\
\hline Protease K & + & + & - & - & - & + & + & - & + \\
\hline Heat $121^{\circ} \mathrm{C}$ for $15 \mathrm{~min}$ & ++ & + & ++ & ++ & ++ & ++ & ++ & ++ & + \\
\hline
\end{tabular}

- , No effect;,$+ 10.1-15$ in $\mathrm{mm} ;++, 15.1-20$ in $\mathrm{mm} ;+++, 20.1-25$ in $\mathrm{mm} ;++++,>25.1$ in $\mathrm{mm}$

Table 3 Antimicrobial activities of cell free supernatant (CFS) of LAB

\begin{tabular}{|c|c|c|c|c|c|c|c|c|c|c|c|c|}
\hline \multirow{3}{*}{$\begin{array}{l}\text { Pathogenic } \\
\text { organisms }\end{array}$} & \multicolumn{11}{|c|}{ Lactic acid bacteria cell free supernatant combination (100 $\mu \mathrm{l})$} & \multirow{3}{*}{$\begin{array}{l}\text { Standard } \\
\text { Strep }(10 \mu \mathrm{g}) / \\
\text { Nys }(30 \mu \mathrm{g})\end{array}$} \\
\hline & \multicolumn{4}{|l|}{$100 \mu \mathrm{l}$} & \multicolumn{3}{|c|}{$50 \mu l+50 \mu l$} & \multicolumn{3}{|c|}{$33 \mu l+33 \mu l+33 \mu l$} & \multirow{2}{*}{$\begin{array}{l}25 \mu \mathrm{l} \text { in each } \\
\text { CFS } \\
(1+2+3+4)\end{array}$} & \\
\hline & CFS 1 & CFS 2 & CFS 3 & CFS 4 & $\begin{array}{l}\text { CFS } \\
(1+2)\end{array}$ & $\begin{array}{l}\text { CFS } \\
(1+3)\end{array}$ & $\begin{array}{l}\text { CFS } \\
(1+4)\end{array}$ & $\begin{array}{l}\text { CFS } \\
(1+2+3)\end{array}$ & $\begin{array}{l}\text { CFS } \\
(1+3+4)\end{array}$ & $\begin{array}{l}\text { CFS } \\
(2+3+4)\end{array}$ & & \\
\hline \multicolumn{6}{|c|}{ Gram positive bacteria } & \multicolumn{6}{|c|}{ Zone of inhibition (mm) } & \\
\hline B. cereus & 25 & 20 & 27 & 17 & 15 & 28 & 23 & 18 & 30 & 22 & 32 & 23 \\
\hline B. subtilis & 24 & 22 & 31 & 12 & 17 & 29 & 22 & 22 & 31 & 25 & 33 & 28 \\
\hline Staphyl. aureus & 28 & 18 & 31 & 22 & 16 & 30 & 28 & 21 & 32 & 24 & 38 & 27 \\
\hline \multicolumn{6}{|c|}{ Gram negative bacteria } & \multicolumn{6}{|c|}{ Zone of inhibition (mm) } & \\
\hline E. coli & 25 & 17 & 28 & 22 & 16 & 27 & 21 & 17 & 34 & 25 & 36 & 25 \\
\hline Shi. dysenteriae & 25 & 15 & 30 & 21 & 14 & 27 & 22 & 15 & 31 & 21 & 37 & 30 \\
\hline Shi. sonnei & 26 & 19 & 27 & 18 & 14 & 28 & 21 & 18 & 35 & 24 & 39 & 21 \\
\hline \multicolumn{6}{|l|}{ Pathogenic fungi } & \multicolumn{6}{|c|}{ Zone of inhibition (mm) } & \\
\hline S. cerevisiae & 22 & 13 & 18 & 16 & 13 & 22 & 23 & 16 & 26 & 17 & 28 & 21 \\
\hline A. niger & 19 & 15 & 20 & 15 & 13 & 23 & 24 & 16 & 27 & 15 & 27 & 20 \\
\hline C. albicans & 26 & 12 & 18 & 12 & 15 & 26 & 25 & 20 & 29 & 17 & 31 & 23 \\
\hline
\end{tabular}


Table 4 Antimicrobial activities of LAB extracts

\begin{tabular}{|c|c|c|c|c|c|c|c|c|c|c|c|c|}
\hline \multirow{3}{*}{$\begin{array}{l}\text { Pathogenic } \\
\text { organisms }\end{array}$} & \multicolumn{11}{|c|}{ Lactic acid bacteria extract combination $(100 \mu \mathrm{g})$} & \multirow{3}{*}{$\begin{array}{l}\text { Standard } \\
\text { Strep }(30 \mu \mathrm{g}) \\
\text { Nys }(30 \mu \mathrm{g})\end{array}$} \\
\hline & \multicolumn{4}{|c|}{$100 \mu \mathrm{g}$} & \multicolumn{3}{|c|}{$50 \mu \mathrm{g}+50 \mu \mathrm{g}$} & \multicolumn{3}{|c|}{$33 \mu \mathrm{g}+33 \mu \mathrm{l}+33 \mu \mathrm{g}$} & \multirow{2}{*}{$\begin{array}{l}25 \mu \mathrm{g} \text { in each } \\
\text { Ext } \\
(1+2+3+4)\end{array}$} & \\
\hline & Ext 1 & Ext 2 & Ext 3 & Ext 4 & $\begin{array}{l}\text { Ext } \\
(1+2)\end{array}$ & $\begin{array}{l}\text { Ext } \\
(1+3)\end{array}$ & $\begin{array}{l}\text { Ext } \\
(1+4)\end{array}$ & $\begin{array}{l}\text { Ext } \\
(1+2+3)\end{array}$ & $\begin{array}{l}\text { Ext } \\
(1+3+4)\end{array}$ & $\begin{array}{l}\text { Ext } \\
(2+3+4)\end{array}$ & & \\
\hline \multicolumn{6}{|c|}{ Gram positive bacteria } & \multicolumn{6}{|c|}{ Zone of inhibition (mm) } & \\
\hline B. cereus & 19 & 15 & 21 & 16 & 11 & 23 & 22 & 17 & 25 & 21 & 27 & 22 \\
\hline B. subtilis & 18 & 17 & 19 & 13 & 12 & 24 & 24 & 21 & 24 & 22 & 29 & 29 \\
\hline Staphyl. aureus & 22 & 15 & 20 & 18 & 12 & 25 & 23 & 18 & 23 & 20 & 32 & 22 \\
\hline \multicolumn{6}{|c|}{ Gram negative bacteria } & \multicolumn{6}{|c|}{ Zone of inhibition (mm) } & \\
\hline E. coli & 19 & 17 & 20 & 19 & 12 & 24 & 20 & 14 & 25 & 25 & 26 & 24 \\
\hline Shi. dysenteriae & 21 & 15 & 21 & 18 & 13 & 23 & 22 & 16 & 24 & 21 & 27 & 22 \\
\hline Shi. sonnei & 20 & 12 & 20 & 19 & 13 & 24 & 19 & 17 & 25 & 24 & 29 & 25 \\
\hline \multicolumn{6}{|l|}{ Pathogenic fungi } & \multicolumn{6}{|c|}{ Zone of inhibition (mm) } & \\
\hline S. cerevisiae & 15 & 11 & 17 & 14 & 12 & 21 & 21 & 15 & 21 & 15 & 25 & 21 \\
\hline A. niger & 15 & 12 & 16 & 12 & 12 & 22 & 22 & 14 & 22 & 16 & 24 & 20 \\
\hline C. albicans & 17 & 10 & 13 & 10 & 11 & 23 & 23 & 18 & 24 & 14 & 23 & 23 \\
\hline
\end{tabular}

Strep streptomycin and Nys nystatin

isolated from LAB1- 4 and tested against pathogenic bacteria and fungi (Tables 3 and 4). A sequential synergistic suppressive effect was observed for the combinations of CFS1,3; CFS1,3,4 and CFS1,2,3,4 and significantly reduced multiplication of different pathogens such as Staphylococcus aureus, Shigella sonnei or Candida albicans. These data suggested that combination of LAB 1, 2, 3 and 4 strains showed a maximal antagonistic activity against pathogenic organisms. From the results, it is suggested that the co-cultures of these strains would be beneficial in controlling the growth of pathogens in acidic media like fruit juices. To investigate the bacteriocin like inhibitory substance (BLIS) activity, the Ext1, 2, 3 or 4 were mixed in different proportions and tested against Staphyl. aureus, Bacillus cereus, B. subtilis, Escherichia coli, Shi. dysenteriae and Shi. sonnei (Table 4). The BLIS of Ext1 showed the highest inhibition against Staphyl. aureus, Shi. dysenteriae, Shi. sonnei, B. cereus, E. coli and $B$. subtilis where the zones of inhibition were 2.2, $2.1,2.0,1.9,1.9$ and $1.8 \mathrm{~cm}$ respectively. However, the antimicrobial activities were increased when the extracts were given in different combinations. Ext1 and 3 showed a better activity, Ext 2 and 4 showed mild to moderate activities against all the test organisms. Interestingly, the combined form, Ext 1- 4 exhibited the greater synergistic antagonism against Staphyl. aureus, B. subtilis and Shi. sonnei.

\section{Susceptibility of LAB to antibiotics}

The LAB1-4 and pathogens like B. cereus, B. subtilis, Staphyl. aureus, E. coli, Shi. dysenteriae and Shi. sonnei varied in their sensitivity to different antibiotics. The results suggested that the LAB 1 and 2 were resistant to different antibiotics whereas LAB 3 and 4 were susceptible only for amoxicillin, ciprofloxacin and penicillin $\mathrm{G}$. It was noted that all of the $\mathrm{LAB}$ were susceptible to the food preservatives and the zone of inhibition was less than $10 \mathrm{~mm}$ which assured resistance to antibiotics.

\section{Survival rates of free-form and microencapsulated LAB in OJ}

The survival rates of both unencapsulated and encapsulated Lactobacilli included into OJ was given in Fig. 2a and $\mathrm{b}$. Unencapsulated LAB in co-cultures degenerated quickly in the $\mathrm{OJ}$ within $4 \mathrm{wks}$ and there were no viable LAB left by the fifth wk (Fig. 2a). In free-form, most of the LAB in monocultures and co-cultures appeared in comparable depletion of viability. However, a synergistic action occurred when LAB 1- 4 was given in combination and the viable bacteria were found to be maximal than that of individual cultures and other co-culture system. Free-form LAB disappeared gradually when compared to monocultured bacteria in the OJ within 4 wks. At the beginning of fifth wk, the viable bacteria were approximately $10^{4} \mathrm{CFU} / \mathrm{mL}$. Since, OJ was acidic and the survival rate of multiple co-cultured probiotic bacteria was enhanced than any monocultured bacteria. The deprivation of encapsulated bacteria in OJ was apparently stable in respect to their viability as compared to the free-form bacteria and the bacteria were present about $10^{6} \mathrm{CFU} / \mathrm{mL}$ at the end of 6 wks (Fig. $2 \mathrm{~b}$ ).

\section{Biopreservation and stability of $\mathrm{OJ}$}

The results of preservative activity of LAB were shown in Fig. 3. The variation of $\mathrm{pH}$ in $\mathrm{OJ}$ inoculated unencapsulated and microencapsulated LAB and their preservative 

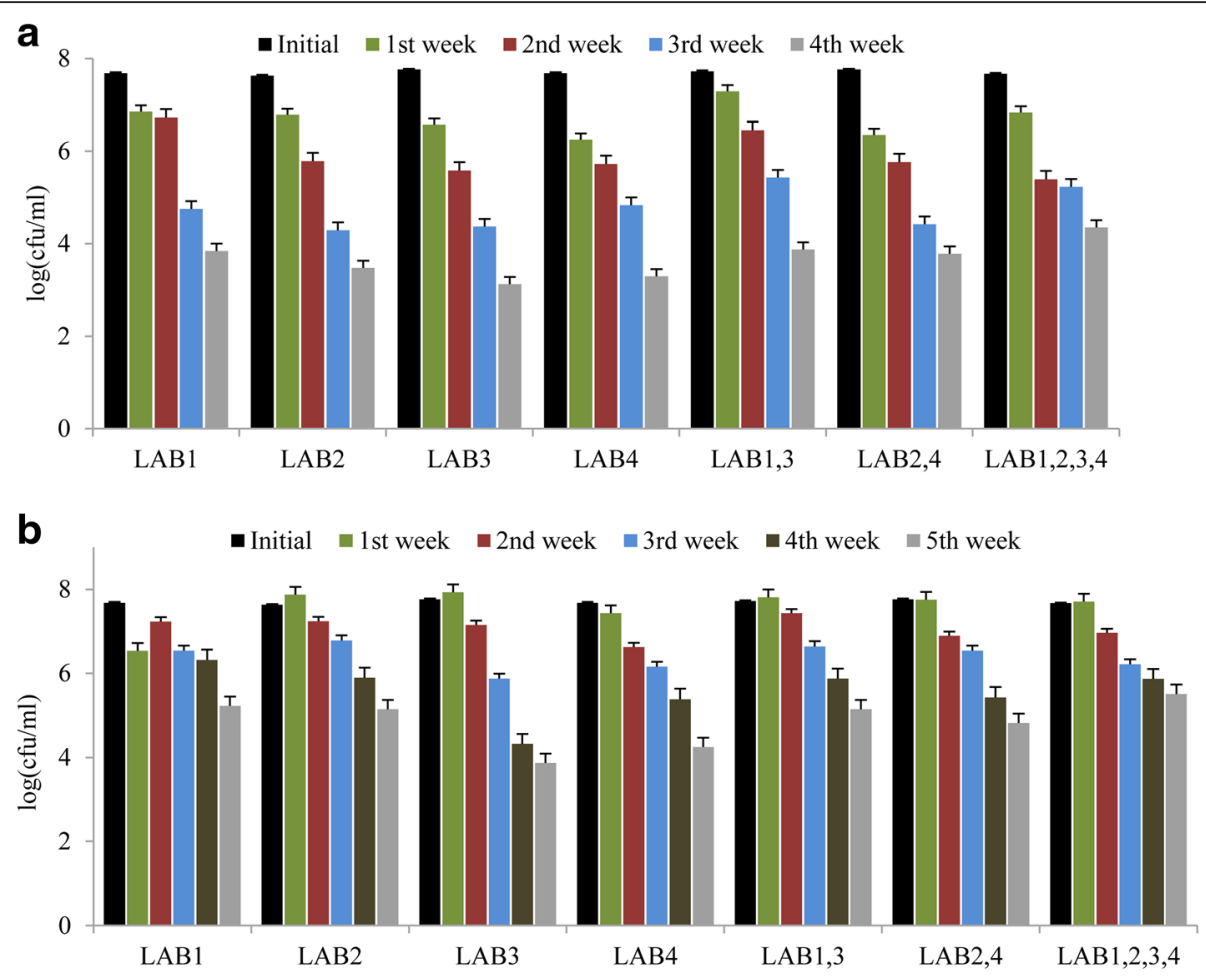

C Free LAB1,2,3,4 - Microencapsulated LAB1,2.3.4

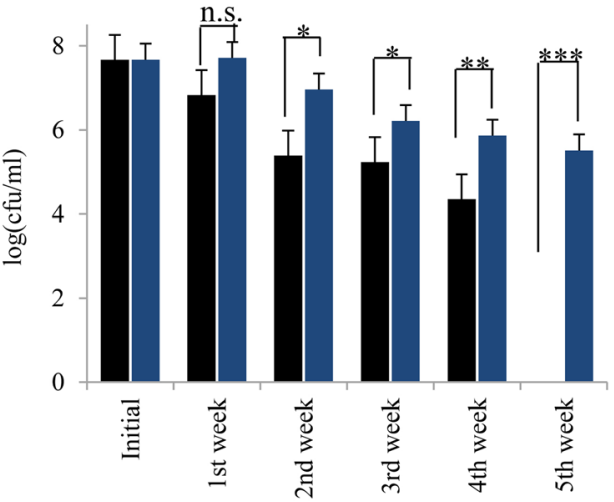

Fig. $2 L A B$ preserved $O J$ stored at $4{ }^{\circ} \mathrm{C}$ over a period of 5 wks. a Free form $L A B$; b Microencapsulated $L A B$; c Comparison of viable $C F U$ of free form and microencapsulated $L A B$

effects during 4-6 wks storage condition were delineated in Fig. 3. An identical fashion in the fall of $\mathrm{pH}$ was observed in both free-form and encapsulated LAB 1-4 in OJ. However, the terminal $\mathrm{pH}$ of $\mathrm{OJ}$ immersed with encapsulated LAB during 6 wks storage condition was larger than that inoculated with free form bacteria. The $\mathrm{pH}$ of OJ entrapped free-form bacteria reduced from 3.94 to 2.71 at the end of 4 wks (Fig. 3a). On the other hand, the pH of the juice comprised of encapsulated LAB dropped to only 3.3 during that period of storage (Fig. $3 \mathrm{~b}$ ). This data confirms that microencapsulated LAB state had a more endurable and feasible for survival condition and was consistent with Ding group [20].
The preservative action of LAB had been attributed due to the decreasing $\mathrm{pH}(\geq 4)$ by secreting organic acids and this property was effective to inhibit the growth of pathogenic microorganisms, the causative agents of food spoilage and diseases [25]. By maintaining the lower $\mathrm{pH}$, $\mathrm{LAB}$ can prolong the shelf life of fermented food. In order to examine the preservative action of $\mathrm{LAB}$ in $\mathrm{OJ}$, we evaluated the variation of $\mathrm{pH}$ and light transmission in OJ only; OJ contaminated with pathogenic bacteria (PB); OJ inoculated with LAB1-4 and chemically preserved OJ (preservative PR; propyl- and methyl paraben, ratio 5:1). The LAB1-4 inoculated OJ lowered the $\mathrm{pH}$ from 3.94 to 3.3 and light transmission was approximately 


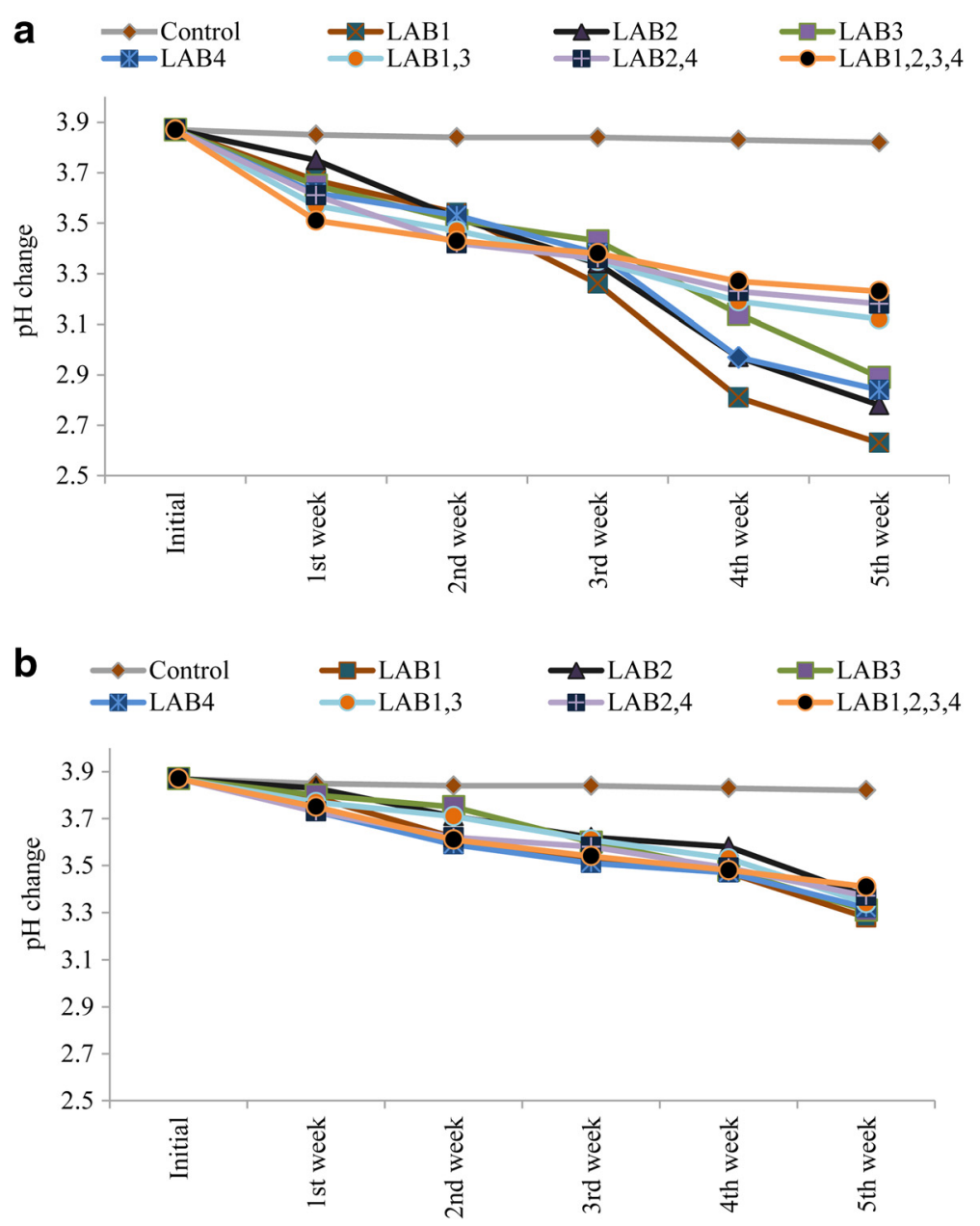

Fig. 3 pH change in OJ containing free and microencapsulated LAB. a Free LAB containing OJ; b Microencapsulated LAB containing OJ

$50 \%$ (Fig. 4a and b). At the end of $48 \mathrm{~h}, \mathrm{pH}$ increased in free-form OJ due to somehow microorganisms contaminated the juice, and in $\mathrm{PB}$ infected OJ. Comparing to LAB1-4 in OJ, the OJ had almost stable $\mathrm{pH}$ when chemical preservative was used (Fig. 4a). After 48 h, turbidity also increased in only $\mathrm{OJ}$ and $\mathrm{OJ}$ containing $\mathrm{PB}$. However, the light transmission were approximately similar in LAB inoculated OJ and PR inserted OJ (Fig. 4b).

\section{Discussion}

The overestimation of probiotic amounts in all pharmaceutical products tested could be due to many factors. It might be happened that firstly, sub-optimal methodological procedures were used with respect to rehydration conditions and sample homogenization [15, 26]. However, this factor alone was not sufficient to explain the large differences in CFUs reached and those claimed. Therefore, other potential problems have occurred: 1) a large number of bacteria were destroyed during different stages of processing and sometimes, the manufacturing companies intentionally exaggerated the contents in their probiotic products $[27,28], 2)$ the product was not dried enough and a high water activity in the powder was detrimental to viability during storage, 3) an efficient antioxidant was absent in the product, 4) packaging did not prevent the entrance of moisture or oxygen in the product during storage, 5) storage temperature was not cold enough or there was indiscriminate handling and storage conditions (cold chains) [23]. It was reported that probiotic products should be consumed regularly, at a daily intake of approximately $10^{9}$ viable cells [29]. However, in our current study, among five commercial probiotic product none of them were shown to have the minimum level. Thus, it is impractical and questionable that the health recovery from the low quality products can be acquired by the insufficient number of viable probiotics [30]. Thus, this study provides a meaningful and useful fundamental data on exactness and reliability of information regarding probiotic bacteria described on the leaflets of pharmaceutical products where legislations 


\section{Before after}
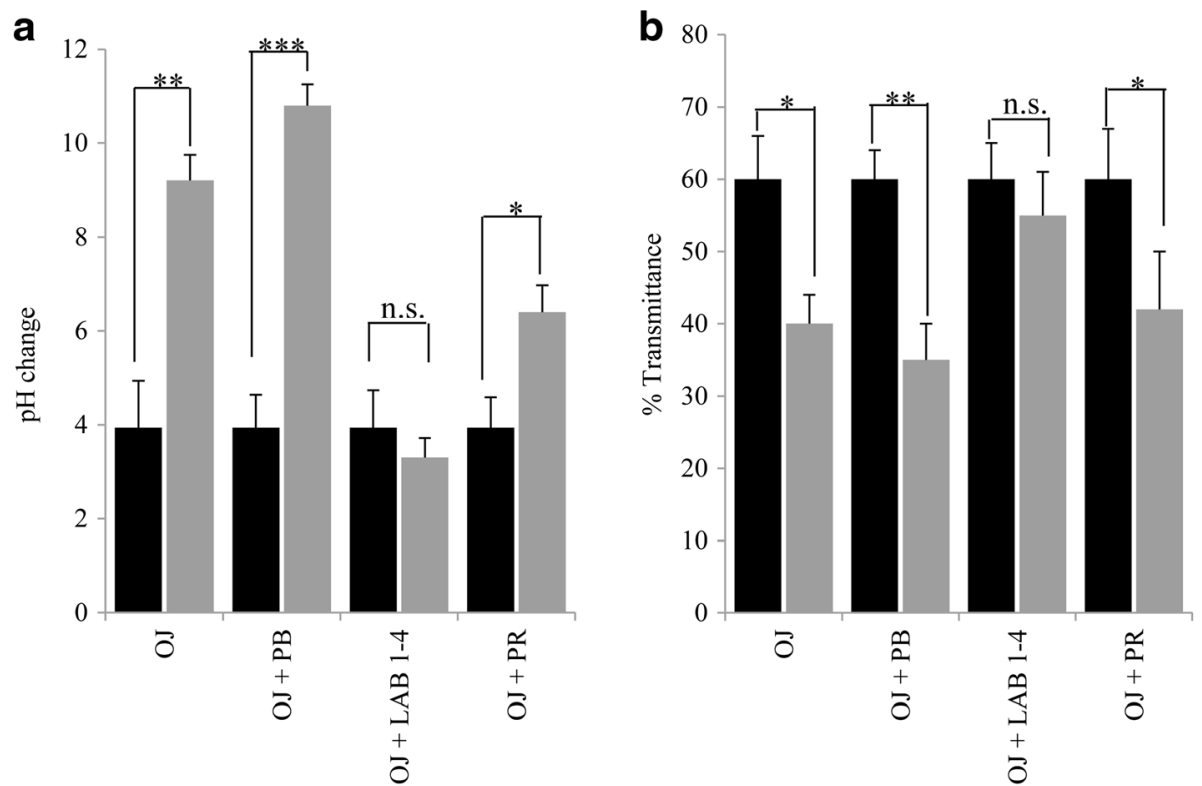

Fig. 4 Effects of $\mathrm{pH}$ and transmittance of light on inoculation of LAB1- 4 in OJ. a pH change; $\mathbf{b}$ transmittance of light. OJ, orange juice; PB, pathogenic bacteria; LAB, lactic acid bacteria; PR, food preservative

and regulations about the labeling of products are recently obscures [31]. The ideal situation should be as is done in Canada, where the stated counts must be obtained at the terminal of storage time, and higher populations than those claimed are therefore packaged in order to allow for viability losses during storage. At a minimum, as done by some manufacturers in the USA, a disclaimer is made on the package which states that the CFUs are only those when the product left the factory; this warns consumers that CFUs could be lower should the product suffer abuse during storage.

Because LAB produce some known organic acids like lactic acid or acetic acid, which are important for enabling the LAB to suppress pathogenic Gram-negative and -positive bacteria [32]. Thus, the inhibitory activities of LAB might be associated with the production of organic acids or acidic molecules. After exclusion of $\mathrm{H}_{2} \mathrm{O}_{2}$ by catalase, the resulting mixtures of CFSs also moderately lowered the inhibition activities of all LAB. Whenever bacteriocin-like metabolites were digested by proteinase $\mathrm{K}$, the antagonistic activities of all LAB dramatically abolished indicating that bacteriocin-like metabolites had a greater role in inhibition of pathogenic bacteria and fungi. Many of bacteriocin-like metabolites are either heat stable or heat-labile. So, we checked the effects of heat after treating at $121{ }^{\circ} \mathrm{C}$ for $15 \mathrm{~min}$ and found that CFS1 and 3 were stable and active against pathogenic bacteria and fungi, and the other CFSs lost their antimicrobial activities.
Antibiotics have been necessary to combat against infectious agents and have been associated with the increase of life span. However, antimicrobial resistance has become gradually a global threat of public health where antibiotics are no longer effective against pathogenic bacteria. The boundless antibiotic resistance is attributed to excessive, inappropriate or indiscriminate application of antibiotics in many area of the world as a result of chromosomal resistance $[33,34]$. Some ecological communities (e.g., the human gut) are occupied by a special group of microorganisms, called commensal bacteria. The majority of these bacteria inhabited the niches of human gut and most of the cases, these bacteria were supposed to harmless for health. However, sometimes in close proximity, LAB could transfer genetic material carrying antibiotic resistance (AR) genes to highly infectious pathogens $[35,36]$. For these purposes, we investigated the antibiotic resistant screening against the LAB (Table 5). Our results indicate some variations of antibiotic resistances with other reports [15, 37]. These resistances of antibiotics and other pathogenic bacteria were not only conferred by intrinsic genes but also achieved motile genetic elements. This is an important mechanism for transmission of mobile elements (such as plasmids and transposons) from one bacterium to another by conjugation. Indeed, this phenomena has been observed in vitro where antibiotic resistant gene is shifted from one Lactobacillus to another or from Lactobacilli to another species including pathogens like Staphylococcus [37, 38]. 
Table 5 Susceptibility of lactic acid bacteria (LAB) to antibiotics and food-preservative

\begin{tabular}{|c|c|c|c|c|c|c|c|c|c|c|c|c|c|}
\hline & $\begin{array}{l}\text { Amx } \\
(30 \mu g)\end{array}$ & $\begin{array}{l}\text { Cef } \\
(30 \mu \mathrm{g})\end{array}$ & $\begin{array}{l}\text { Chlor } \\
(30 \mu \mathrm{g})\end{array}$ & $\begin{array}{l}\text { Cip } \\
(5 \mu \mathrm{g})\end{array}$ & $\begin{array}{l}\text { Dox } \\
(30 \mu \mathrm{g})\end{array}$ & $\begin{array}{l}\text { Ery } \\
(15 \mu \mathrm{g})\end{array}$ & $\begin{array}{l}\text { Kan } \\
(5 \mu \mathrm{g})\end{array}$ & $\begin{array}{l}\text { Pen } \\
(10 \mu \mathrm{g})\end{array}$ & $\begin{array}{l}\text { Strep } \\
(10 \mu \mathrm{g})\end{array}$ & $\begin{array}{l}\text { Tet } \\
(30 \mu \mathrm{g})\end{array}$ & $\begin{array}{l}\text { SB } \\
(0.1 \%)\end{array}$ & $\begin{array}{l}(\mathrm{M}: \mathrm{P} \\
0.1 \%)\end{array}$ & $\begin{array}{l}\text { MB } \\
(0.1 \%)\end{array}$ \\
\hline LAB 1 & $8(\mathrm{R})$ & $6(\mathrm{R})$ & $8(R)$ & 12 & $8(R)$ & $6(\mathrm{R})$ & $6(\mathrm{R})$ & $8(R)$ & $6(\mathrm{R})$ & $9(\mathrm{R})$ & 15 & 14 & 19 \\
\hline LAB 2 & $6(\mathrm{R})$ & 12 & $8(\mathrm{R})$ & 12 & $8(\mathrm{R})$ & $6(\mathrm{R})$ & $6(\mathrm{R})$ & $10(\mathrm{R})$ & $6(\mathrm{R})$ & $10(\mathrm{R})$ & 14 & 19 & 14 \\
\hline LAB 3 & 19 & $6(\mathrm{R})$ & 13 & 18 & 17 & 18 & $6(\mathrm{R})$ & $10(\mathrm{R})$ & 19 & 11 & 16 & 21 & 17 \\
\hline LAB 4 & 17 & $6(\mathrm{R})$ & $6(\mathrm{R})$ & 13 & $8(\mathrm{R})$ & $6(\mathrm{R})$ & $6(\mathrm{R})$ & $6(\mathrm{R})$ & 21 & $6(\mathrm{R})$ & 18 & 22 & 13 \\
\hline \multicolumn{14}{|c|}{ Gram positive bacteria } \\
\hline B. cereus & $6(\mathrm{R})$ & 28 & 27 & 32 & 19 & 22 & 18 & 17 & 21 & 22 & 11 & 12 & 14 \\
\hline B. subtilis & 17 & 23 & 23 & 26 & $6(\mathrm{R})$ & $12(\mathrm{R})$ & 22 & 22 & 17 & 19 & $6(\mathrm{R})$ & $6(\mathrm{R})$ & $6(R$ \\
\hline Staphyl. aureus & 23 & 31 & 24 & 40 & 21 & $6(\mathrm{R})$ & 18 & 34 & $6(\mathrm{R})$ & 30 & $6(\mathrm{R})$ & $6(\mathrm{R})$ & $6(\mathrm{R}$ \\
\hline \multicolumn{14}{|c|}{ Gram negative bacteria } \\
\hline E. coli & 34 & 22 & 34 & 33 & $0(\mathrm{R})$ & 25 & 27 & $0(\mathrm{R})$ & 23 & 32 & 12 & 16 & 15 \\
\hline Shi. dysenteriae & $6(\mathrm{R})$ & 31 & 33 & $6(\mathrm{R})$ & $8(R)$ & 22 & $10(\mathrm{R})$ & 16 & 23 & 25 & $10(\mathrm{R})$ & $6(\mathrm{R})$ & $6(\mathrm{R})$ \\
\hline Shi. sonnei & 28 & 34 & $9(\mathrm{R})$ & 21 & 23 & $9(\mathrm{R})$ & $6(\mathrm{R})$ & 23 & 15 & 18 & $6(\mathrm{R}$ & $6(\mathrm{R})$ & $9(\mathrm{R})$ \\
\hline \multicolumn{14}{|l|}{ Pathogenic fungi } \\
\hline S. cerevisiae & $6(\mathrm{NR})$ & $6(\mathrm{NR})$ & 6 (NR) & 0 (NR) & 0 (NR) & 0 (NR) & $8(\mathrm{NR})$ & 0 (NR) & 0 (NR) & 0 (NR) & 17 & 18 & 16 \\
\hline A. niger & 0 (NR) & 0 (NR) & 6 (NR) & 0 (NR) & 6 (NR) & 0 (NR) & $0(\mathrm{NR})$ & 6 (NR) & 9 (NR) & $6(\mathrm{NR})$ & 17 & 20 & 18 \\
\hline C. albicans & $0(N R)$ & $0(\mathrm{NR})$ & 6 (NR) & $6(\mathrm{NR})$ & $0(\mathrm{NR})$ & $6(\mathrm{NR})$ & $6(\mathrm{NR})$ & 0 (NR) & 0 (NR) & 0 (NR) & 18 & 18 & 15 \\
\hline
\end{tabular}

$R$ resistance, $S$ susceptible, $N R$ non-response and zone of inhibition in $\mathrm{mm}$

Microcapsules support a suitable anaerobic condition for the growth of susceptible probiotics and give them a physical blockade from the bitter acidic environment in OJ $[13,39]$. The interesting results suggested that the higher survival rate of microencapsulated multiple bacteria were found when inoculated into $\mathrm{OJ}$ than the free form (Fig. 2c). For significant health benefits, it is evident to stay a large number of viable LAB in the probiotic products [40]. However, several factors can affect the survival rates of LAB in these products $[41,42]$. Freeform of bacteria might fermented carbohydrates and released several acids, which in turn lowered the $\mathrm{pH}$ during the storage condition. However, a lot of free bacteria were died at the subsequent stages of storage; although the dead probiotics could secrete enzymes for breakdown sugars in the juice and reduced the $\mathrm{pH}[42,43]$. These data concluded that bacteria in microencapsulation would survive over a longer storage period and could formulate more stable functional foods [43].

In general, probiotic bacteria are utilized in dairy industries for fermentation of sugars in order to provide organic acids such as lactic acid which are associated with the decrease in $\mathrm{pH}$ [44]. In this study, LAB 1- 4 survived in the high acidic OJ. A quick fall in $\mathrm{pH}$ in the starting of fermentation improved the quality of final products as well as minimized the influence of spoilage bacteria. The suppressive activity of probiotic bacteria against pathogens is due to the accumulation of metabolites such as lactic acid as well as antimicrobial compounds such as $\mathrm{H}_{2} \mathrm{O}_{2}$ and antibiotics, bacteriocins.
However, the grade of quality and amounts among these secreting compounds vary on strains of bacteria, culture conditions and other physical properties.

The food spoilage and associated diseases are the major problems in developing countries [45]. In most cases, low level temperature is applied to enhance the shelf life of food products. The ambient temperature is high in maximum days of a year in many countries like Bangladesh. There is also disrupted and intermittent supply of electricity for maintaining low storage temperature inconvenient for most of the people. As a result, pathogenic bacteria and fungi easily attack the food products due to high storage temperature. Although a wide variety of chemical preservatives are available, the food-grade preservation and marketing must be taken into considerations for extended shelf life [46, 47]. Thus, the concept of preservative action of LAB in OJ will become popular in manufacturing of several products by lowering the $\mathrm{pH}$ which prevents the food poisoning and diseases.

\section{Conclusion}

From this study, it was indicted the viability of LAB available probiotic products in Bangladesh were less than that of manufacturers claimed. The entire identified LAB showed antimicrobial activities synergistically against common food spoilage pathogenic microbes. The higher number of viable $\mathrm{LAB}$ were present in microencapsulated $\mathrm{OJ}$ than that of free form and the result indicated that the capability of immobilized LAB preserved OJ for longer time against spoilage owing to restrict the 
growth of pathogenic microorganisms in the OJ. Thus, he microencapsulated probiotics would be used in preservation of food and beverage industry in place of chemical preservatives in the food processing and final products. In the near future, the microencapsulated probiotics may become an alternative vehicle for the production of biopreserved food and as a functional food, biopreserved $\mathrm{OJ}$ will give the prospective beneficial and protective role in human health.

\section{Acknowledgements \\ We acknowledge the support from Ministry of Science and Technology, Bangladesh as 'Research Contract Program under Special Allocation for Science and Technology' as well as National Science and Technology (NST) fellowship funded by Ministry of Science and Communication Technology, Bangladesh. The authors also would like to thank Dean, Faculty of Science for the allocation of Research Project, University of Rajshahi, Bangladesh.}

\section{Funding}

The authors declare that they have no any fund for analysis and interpretation of data and for writing, professional editing and proofreading service of the manuscript.

\section{Availability of data and materials}

All data generated or analyzed during this study were included in this manuscript and the datasets analyzed of the study will be available from the corresponding author on reasonable request.

\section{Authors' contributions}

MSH performed all the experiments on the role of $L A B$ in biopreservation. $M A A B$ designed of the study, choice of assay methods, writing and revised manuscript. MIIW assisted in data analysis and interpretation, and ZHM critically reviewed the manuscript. All the authors revised carefully and approved the final manuscript for submission.

\section{Competing interests}

The authors declare that they have no competing interests.

\section{Consent for publication}

Not applicable for the manuscript.

\section{Ethics approval and consent to participate}

Not applicable for the manuscript.

\section{Author details}

'Department of Pharmacy, University of Rajshahi, Rajshahi 6205, Bangladesh ${ }^{2}$ Environmental Microbiology Laboratory, Centre for Food and Waterborne Diseases, ICDDR'B, Dhaka 1000, Bangladesh.

\section{Received: 3 June 2016 Accepted: 20 August 2016}

\section{Published online: 31 August 2016}

\section{References}

1. Angiolillo L, Conte A, Zambrini AV, Del Nobile MA. Biopreservation of Fior di Latte cheese. J Dairy Sci. 2014;97:5345-55. doi:10.3168/jds.2014-8022.

2. El Bassi L, Hassouna M, Shinzato N, Matsui T. Biopreservation of refrigerated and vacuum-packed Dicentrarchus labrax by lactic acid bacteria. J Food Sci. 2009;74:M335-339. doi:10.1111/j.1750-3841.2009.01246.X.

3. Ruiz FO, Gerbaldo G, Garcia MJ, Giordano W, Pascual L, Barberis IL. Synergistic effect between two bacteriocin-like inhibitory substances produced by Lactobacilli Strains with inhibitory activity for Streptococcus agalactiae. Curr Microbiol. 2012;64:349-56. doi:10.1007/s00284-011-0077-0.

4. Badel S, Bernardi T, Michaud P. New perspectives for Lactobacilli exopolysaccharides. Biotechnol Adv. 2011;29:54-66. doi:10.1016/j. biotechadv.2010.08.011.

5. Songisepp E, Hutt P, Ratsep M, Shkut E, Koljalg S, Truusalu K, et al. Safety of a probiotic cheese containing Lactobacillus plantarum Tensia according to a variety of health indices in different age groups. J Dairy Sci. 2012;95:5495-509. doi:10.3168/jds.2011-4756.
6. Stykova E, Nemcova R, Valocky I, Novotny F, Guba P. Adherence of bacteria to mucus collected from different parts of the reproductive tract of heifers and cows. Can J Microbiol. 2013;59:720-5. doi:10.1139/ cjm-2013-0542.

7. Wells JM, Mercenier A. Mucosal delivery of therapeutic and prophylactic molecules using lactic acid bacteria. Nat Rev Microbiol. 2008;6:349-62. doi:10.1038/nrmicro1840

8. Granato D, Branco GF, Nazzaro F, Cruz AG, Faria JAF. Functional foods and nondairy probiotic food development: Trends, concepts, and products. Compr Rev Food Sci Food Safety. 2010;9:292-302. doi:10.1111/j.1541-4337.2010.00110.x

9. Jankovic I, Sybesma W, Phothirath P, Ananta E, Mercenier A. Application of probiotics in food products-challenges and new approaches. Curr Opin Biotechnol. 2010;21:175-81. doi:10.1016/j.copbio.2010.03.009.

10. Deegan LH, Cotter PD, Hill C, Ross P. Bacteriocins: Biological tools for bio-preservation and shelf-life extension. Intl Dairy J. 2006;16:1058-71. doi:10.1016/j.idairyj.2005.10.026.

11. Yoon KY, Woodams EE, Hang YD. Probiotication of tomato juice by lactic acid bacteria. J Microbiol. 2004;42:315-8.

12. Ding WK, Shah NP. Acid, bile, and heat tolerance of free and microencapsulated probiotic bacteria. J Food Sci. 2007;72:M446-50. doi:10.1111/j.1750-3841.2007.00565.x.

13. Sohail A, Turner MS, Prabawati EK, Coombes AG, Bhandari B. Evaluation of Lactobacillus rhamnosus GG and Lactobacillus acidophilus NCFM encapsulated using a novel impinging aerosol method in fruit food products. Intl J Food Microbiol. 2012;157:162-6. doi:10.1016/j.ijfoodmicro. 2012.04.025.

14. Tanvir EM, Afroz R, Karim N, Mottalib MA, Hossain MI, Islam M, et al. Antioxidant and antibacterial activities of methanolic extract of Bau kul (Ziziphus Mauritiana), an improved variety fruit from Bangladesh. J Food Biochem. 2015;39:139-47. doi:10.1111/jfbc.12109.

15. Champagne CP, Ross RP, Saarela M, Hansen KF, Charalampopoulos D. Recommendations for the viability assessment of probiotics as concentrated cultures and in food matrices. Intl J Food Microbiol. 2011;149:185-93.

16. Hossain MS, Al-Bari MAA, Wahed MII. Biochemical characterization of probiotics available in Bangladesh. J Sci Res. 2016; 8:101-108. doi: http://dx. doi.org/10.3329/jsr.v8i1.25299.

17. Georgieva R, Yocheva L, Tserovska L, Zhelezova G, Stefanova N, Atanasova A, et al. Antimicrobial activity and antibiotic susceptibility of Lactobacillus and Bifidobacterium spp. intended for use as starter and probiotic cultures. Biotechnol Biotechnol Equip. 2015;29:84-91. doi:10.1080/13102818.2014.987450.

18. Vandepitte J, Verhaegen J, Engbaek K, Rohner P, Piot P, Heuck CC. Basic laboratory procedures in clinical bacteriology. 2nd ed. Geneva: World Health Organization; 2003.

19. Pereira-Caro G, Oliver CM, Weerakkody R, Singh T, Conlon M, Borges G, et al. Chronic administration of a microencapsulated probiotic enhances the bioavailability of orange juice flavanones in humans. Free Radical Biol Med. 2015;84:206-14. doi:10.1016/j.freeradbiomed.2015.03.010.

20. Ding WK, Shah NP. Survival of free and microencapsulated probiotic bacteria in orange and apple juices. Intl Food Res J. 2008;15(2):219-32.

21. Shah NP, Ravula RR. Influence of water activity on fermentation, organic acids production and viability of yogurt and probiotic bacteria. Aust J Dairy Technol. 2000;55:127-31.

22. Zhang T, McCarthy J, Wang G, Liu Y, Guo M. Physiochemical properties, microstructure, and probiotic survivability of nonfat goats' milk yogurt using heat-treated whey protein concentrate as fat replacer. J Food Sci. 2015;80:M788-94. doi:10.1111/1750-3841.12834

23. Wong A, Ngu DYS, Dan LA, Ooi A, Lim RLH. Detection of antibiotic resistance in probiotics of dietary supplements. Nutr J. 2015;14:95. doi:10.1186/s12937015-0084-2.

24. Selim AS, Haider G. Studies on the viabile bacteria of commercial probiotic products available in Bangladesh. World J Microbiol. 2014;1:010-2.

25. Cleveland J, Montville TJ, Nes IF, Chikindas ML. Bacteriocins: safe, natural antimicrobials for food preservation. Intl J Food Microbiol. 2001;71:1-20.

26. Champagne $\mathrm{CP}$, Raymond $\mathrm{Y}$, Tompkins TA. The determination of viable counts in probiotic cultures microencapsulated by spray-coating. Food Microbiol. 2010:24:1104-11.

27. Farnworth ER. The evidence to support health claims for probiotics. J Nutri. 2008:138:1250S-4S.

28. Hamilton-Miller JM, Shah S, Winkler JT. Public health issues arising from microbiological and labelling quality of foods and supplements containing probiotic microorganisms. Public Health Nutri. 1999;2:223-9. 
29. de Souza Oliveira RP, Perego P, de Oliverira MN, Converti A. Effect of inulin as prebiotic and synbiotic interactions between probiotics to improve fermented milk firmness. J Food Engineer. 2011;107:36-40. doi:10.1016/j. jfoodeng.2011.06.005.

30. Lahtinen SJ. Probiotic viability - does it matter? Microbial Ecol Health Dis. 2012;23:18567. doi:10.3402/mehd.v23i0.18567.

31. Przyrembel H. Consideration of possible legislation within existing regulatory frameworks. Am J Clin Nutri. 2001;73:471S-5S.

32. Gillor $\mathrm{O}$, Etzion A, Riley MA. The dual role of bacteriocins as anti- and probiotics. Appl Microbiol Biotechnol. 2008;81:591-606. doi:10.1007/s00253008-1726-5.

33. Costelloe C, Metcalfe C, Lovering A, Mant D, Hay AD. Effect of antibiotic prescribing in primary care on antimicrobial resistance in individual patients: systematic review and meta-analysis. BMJ. 2010;340:c2096. doi:10.1136/bmj.c2096.

34. Goossens H, Ferech M, Vander Stichele R, Elseviers M. Outpatient antibiotic use in Europe and association with resistance: a cross-national database study. Lancet. 2005;365:579-87. doi:10.1016/S0140-6736(05)70799-6.

35. Devirgiliis C, Zinno P, Perozzi G. Update on antibiotic resistance in foodborne Lactobacillus and Lactococcus species. Front Microbiol. 2013;4:301. doi:10.3389/ fmicb.2013.00301.

36. Gueimonde M, Sánchez B, de los Reyes-Gavilán CG, Margolles A. Antibiotic resistance in probiotic bacteria. Front Microbiol. 2013;4:202. doi:10.3389/ fmicb.2013.00202.

37. Djordjevic SP, Stokes HW, Chowdhury PR. Mobile elements, zoonotic pathogens and commensal bacteria: conduits for the delivery of resistance genes into humans, production animals and soil microbiota. Front Microbiol. 2013;4:86. doi:10.3389/fmicb.2013.00086.

38. Rolain JM. Food and human gut as reservoirs of transferable antibiotic resistance encoding genes. Front Microbiol. 2013;4:173. doi:10.3389/fmicb. 2013.00173

39. Tsen JH, Lin YP, An-Erl KV. Fermentation of banana media by using k-carrageenan immobilized Lactobacillus acidophilus. Intl J Food Microbiol. 2004;91:215-20

40. Ford AC, Quigley EM, Lacy BE, Lembo AJ, Saito YA, Schiller LR, et al. Efficacy of prebiotics, probiotics, and synbiotics in irritable bowel syndrome and chronic idiopathic constipation: systematic review and meta-analysis. Am J Gastroenter. 2014;109:1547-61. doi:10.1038/ajg.2014.202.

41. Ding WK, Shah NP. An improved method of microencapsulation of probiotic bacteria for their stability in acidic and bile conditions during storage. J Food Sci. 2009;74:M53-61. doi:10.1111/j.1750-3841.2008.01030.x.

42. Kailasapathy K. Survival of free and encapsulated probiotic bacteria and their effect on the sensory properties of yoghurt. LWT - Food Sci Technol. 2006;39:1221-7. doi:10.1016/j.lwt.2005.07.013

43. Saarela M, Alakomi HL, Mättö J, Ahonen AM, Tynkkynen S. Acid tolerant mutants of Bifidobacterium animalis subsp. lactis with improved stability in fruit juice. LWT Food Sci Technol. 2011;44:1012-8.

44. Aneja KR, Dhiman R, Aggarwal KN, Aneja A. Emerging preservation techniques for controlling spoilage and pathogenic microorganisms in fruit juices. Intl J Microbiol. 2014. http://dx.doi.org/10.1155/2014/758942.

45. Jabeen F, Qazi Jl. Potential of bacterial chitinases and exopolysaccharides for enhancing shelf life of food commodities at varying conditions. Intl Res J Environ Sci. 2014;3:87-93.

46. Fuglsang CC, Johansen CC, Christgau SS, Adler-Nissen J. Antimicrobial enzymes: Applications and future potential in the food industry. Trends Food Sci Technol. 1995;6:390-6

47. Pérez-Pérez C, Regalado-González C, Rodríguez-Rodríguez CA, BarbosaRodríguez JR, Villaseñor-Ortega F. Incorporation of antimicrobial agents in food packaging films and coatings. Adv Agri Food Biotechnol. 2006;37:193-216.

\section{Submit your next manuscript to BioMed Central and we will help you at every step:}

- We accept pre-submission inquiries

- Our selector tool helps you to find the most relevant journal

- We provide round the clock customer support

- Convenient online submission

- Thorough peer review

- Inclusion in PubMed and all major indexing services

- Maximum visibility for your research

Submit your manuscript at www.biomedcentral.com/submit

) Biomed Central 